\title{
Prevalence of Gastro-intestinal Parasites in Horses and Donkeys in Al Diwaniyah Governorate
}

\author{
H. Y. Wannas Kh. A. Dawood Gh. A. Gassem \\ Vet. Med. Coll. /Unive. of Al Qadisiya
}

\begin{abstract}
The study was included hundred of fecal samples of horses and donkeys (44 horses and 56 donkeys) males and females at age (2-6) years were collected from the period (1/11/2009$30 / 10 / 2010$ ). The parasites were encounter in 100\% of horses and donkeys. Among the parasites that detected in horses, the prevalence of Strongylidae, Parascaris equorum, Strongyloides westri, Trichostrongylus axei, Oxyuris equi Cryptosporidium spp., Balantidium coli and Eimeria spp. were 50\% , 40.90\%, 22.72\%, 25\% ,11.36\%, 20.45\% 15.90\% 6.81\% respectively. In donkeys, the prevalence of Strongylidae, Parascaris equorum, Strongyloides westri, Trichostrongylus axei, Oxyuris equi, Dictyocaulus arnfieldi, Cryptosporidium spp., Balantidium coli, Eimeria spp. and Entamoeba coli were 57.14\%, 32.14\%, 28.57\%, 17.85\%, $17.85 \%, 17.85 \%, 19.64,17.85 \%, 10.71 \%$ and $3.57 \%$ respectively. The single parasitic infection in this research was $50 \%, 28.57 \%$ and the mixed infection was $50 \%, 71.42 \%$ in horses and donkeys respectively. The statistical analysis reveal significant differences in the percentages of infections in different ages in horses and donkeys $(p<0.01)$, while there were no significant differences in the percentages of infections of males and females of horses and donkeys $(\mathrm{p}<0.05)$.
\end{abstract}

\section{Introduction}

Equines are said to have the largest collection of parasites of all domestic livestock. These parasites cause damage to the animals both during the infection phase and then again after these larval stages have emerged and developed fully to adult parasites (2). In parasitological studies carried out in different cities of Iraq on horses and donkeys, helminthic infections were reported in horses (3-6) and donkeys

\section{Material and Methods}

In this study, 100 faecal samples, 44 of horses ( 24 females and 20 males) and 56 of donkeys (30 females and 26 males) collected from city center, Al-Shafeya, AlSaniya, Al-Daghara and Khairy village were examined. The ages of animals ranged (2-6) years. The samples of fresh faeces were placed in nylon bags and sent
(7), based on faecal examinations. In addition, protozoal infections occur in horses and donkeys. In horses, (8) was recorded four genera of protozoa and (9) was recorded Eimeria spp. in horses in Mosul city. This study was carried out to determine the prevalence of endoparasites according to faecal examination in horses and in donkeys in Al Diwaniyah city.

to the laboratory for parasitological examinations. The samples were examined with Sheather's sugar saturated flotation method, sedimentation method, and direct smear method. The Diagnosis of the eggs and larvae depended on the special shape of each one (10).

\section{Results}

The prevalence of parasitic infections based on faecal examinations, was found to be $100 \%$ in horses and donkeys and in all areas where the samples were collected including the horses center of Noria. As it was demonstrated in fecal examinations, among parasites determined in horses, the prevalence of Strongylidae (50\%), $\begin{array}{lrr}\text { Parascaris } & \text { equorum } & (40.90 \%), \\ \text { Strongyloides } & \text { westri } & (22.72 \%),\end{array}$ Trichostrongylus axei (25\%), Oxyuris equi $(11.36 \%)$, table 1, and 19 horses (43.18\%) affect with intestinal protozoa, it were Cryptosporidium spp. (20.45\%), Balantidium coli (15.90\%) and Eimeria spp. (6.81\%), table 3.Regarding to donkeys 
$55(98.21 \%)$ of them were infected with nematodes, it were Strongylidae $(57.14 \%)$, Parascaris equorum (32.14\%), Strongyloides westri $(28.57 \%)$. The prevalence of Trichostrongylus axei, Oxyuris equi and Dictyocaulus arnfieldi were $17.85 \%$, table 2 . Fecal examinations prove that 29 donkeys $(51.78 \%)$ affect with intestinal protozoa, it were Cryptosporidium spp. (19.64), Balantidium coli $(17.85 \%)$, Eimeria spp. (10.71\%) and Entamoeba coli (3.57\%), table 3.

Table (1) the number and percentage of infection with each one of nematodes in both sex of horses

\begin{tabular}{|l|l|l|l|l|l|l|}
\hline \multirow{2}{*}{ Nematodes } & \multicolumn{2}{|c|}{ Males } & \multicolumn{2}{c|}{ Females } & \multicolumn{2}{c|}{ Total } \\
\cline { 2 - 7 } & No. & $\%$ & No. & $\%$ & No. & $\%$ \\
\hline Strongyles spp. & 12 & 60 & 10 & 41.66 & 22 & 50 \\
\hline O. equi & 3 & 15 & 2 & 8.33 & 5 & 11.36 \\
\hline P. equorum & 10 & 50 & 8 & 33.33 & 18 & 40.90 \\
\hline T. axei & 5 & 25 & 6 & 25 & 11 & 25 \\
\hline S. westri & 5 & 25 & 5 & 20.83 & 10 & 22.72 \\
\hline
\end{tabular}

Table (2) the number and percent of infection with each one of nematodes in both sex of donkeys:

\begin{tabular}{|l|c|l|l|l|l|l|}
\hline \multirow{2}{*}{ Nematodes } & \multicolumn{2}{|c|}{ Males } & \multicolumn{2}{c|}{ Females } & \multicolumn{2}{c|}{ Total } \\
\cline { 2 - 8 } & No. & $\%$ & No. & $\%$ & No. & $\%$ \\
\hline Strongyles spp. & 20 & 76.92 & 12 & 40 & 32 & 57.14 \\
\hline Oxyuris equi & 7 & 26.92 & 3 & 10 & 10 & 17.85 \\
\hline Parascaris equorum & 6 & 23.07 & 12 & 40 & 18 & 32.14 \\
\hline Tricostrongylus axei & 5 & 19.23 & 5 & 16.60 & 10 & 17.85 \\
\hline Strongyliodes westri & 10 & 38.46 & 6 & 20 & 16 & 28.57 \\
\hline Dictyocalus arnfieldi & 8 & 30.76 & 2 & 6.60 & 10 & 17.85 \\
\hline
\end{tabular}

Table (3) the number and percentage of protozoal infection of horses and donkeys:

\begin{tabular}{|l|l|l|l|l|}
\hline \multirow{2}{*}{ Protozoal species } & \multicolumn{2}{|c|}{ Horse } & \multicolumn{2}{c|}{ Donkeys } \\
\cline { 2 - 5 } & No. & $\%$ & No. & $\%$ \\
\hline Eimeria spp. & 3 & 6.81 & 6 & 10.71 \\
\hline Cryptosporidium spp. & 9 & 20.45 & 11 & 19.64 \\
\hline Balantidium coli & 7 & 15.90 & 10 & 17.85 \\
\hline Entameoba coli & - & - & 2 & 3.57 \\
\hline Total & 19 & 43.18 & 29 & 51.78 \\
\hline
\end{tabular}

The diagnosis of eggs and larvae of Strongyles Spp. (figure 1), eggs of $P$. equorum (fig. 2), eggs of $S$. westri (fig. 3), eggs and larvae of $D$. arnfieldi (fig. 4), eggs and female of $O$. equi (fig. 5), eggs of $T$. axei (fig. 6), the special form of ciliated protozoa B. coli (fig. 7) was done and the oocyst of Eimeria spp. and Cryptosporidium spp. (fig.8,9). The post morteum examination shows the attachment of Gasterophilus intestinalis at the wall of stomach and makes pits (fig.8, 9). 


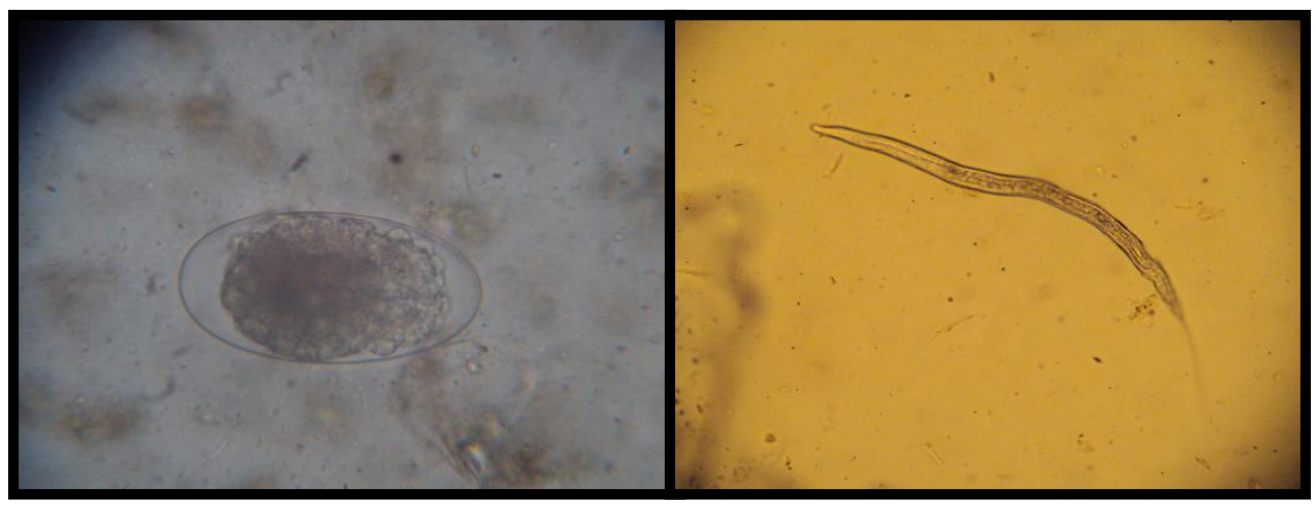

Fig. (1) Egg and larvae of Strongylus spp. in flotation method X40

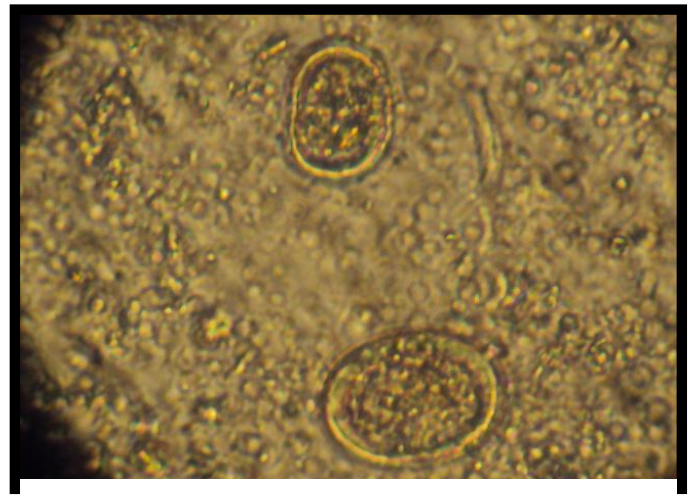

Fig. (2) Eggs of Parascaris equorum in flotation method $\mathrm{X} 40$

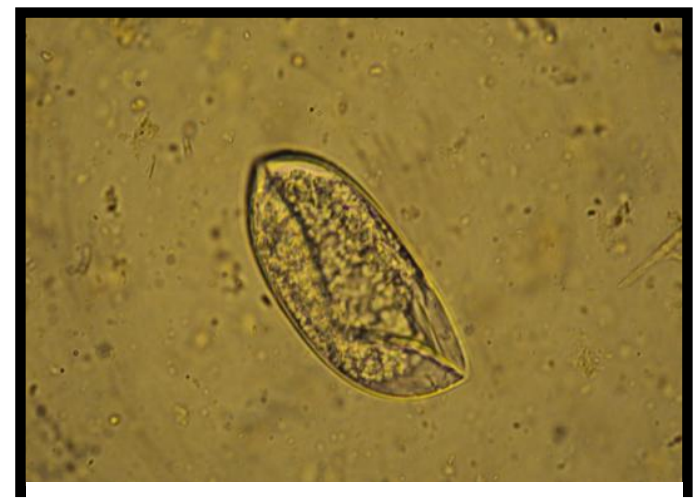

Fig. (3) Egg of Strongyloides westri in flotation method X40

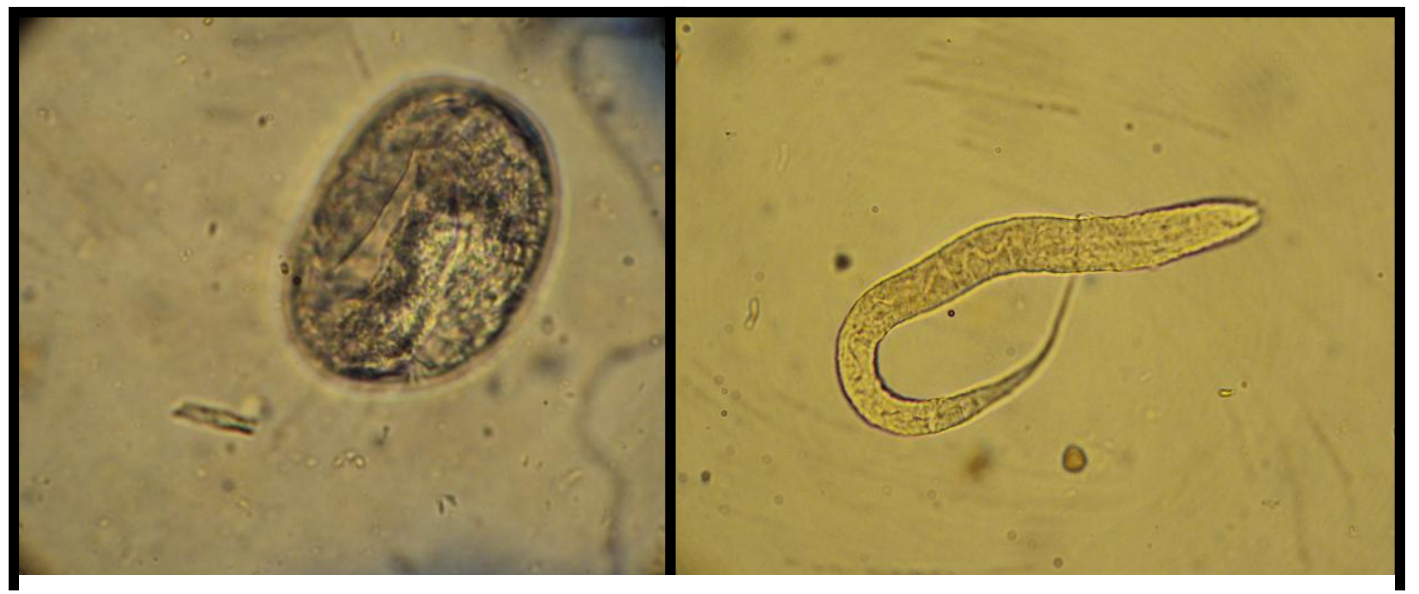

Fig.(4) Larvated egg of and larvae of Dictyocaulus arnfieldi. in flotation method $40 \mathrm{X}$ 


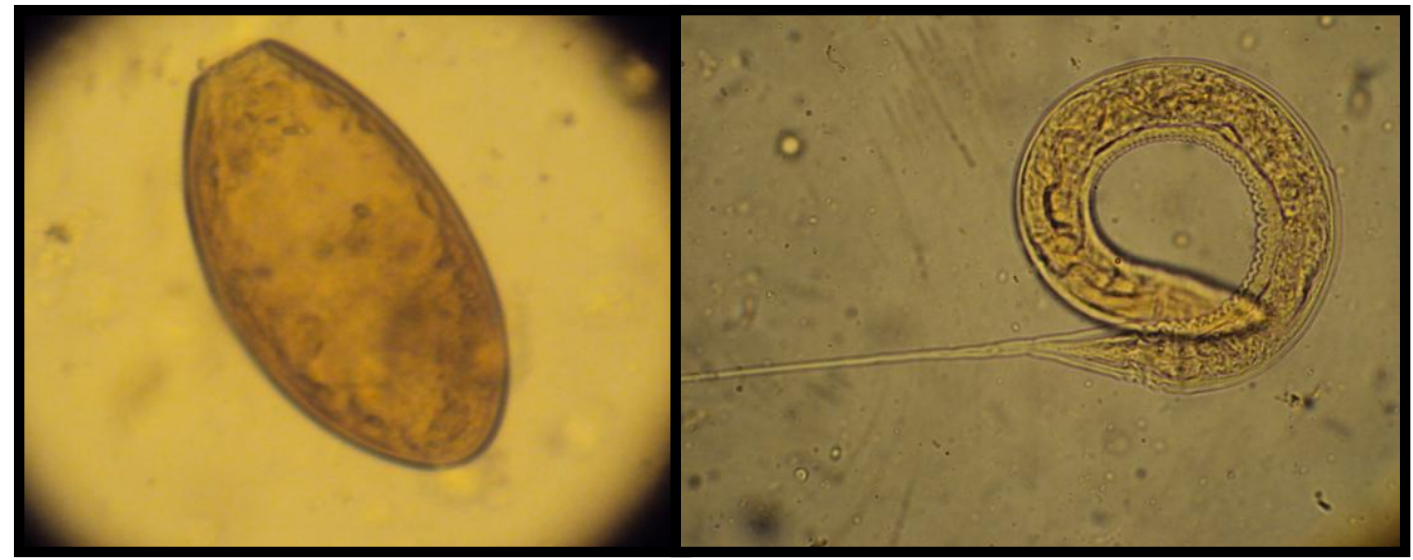

Fig. (5) Egg of and female of Oxyuris equi in direct smear method $40 \mathrm{X}$

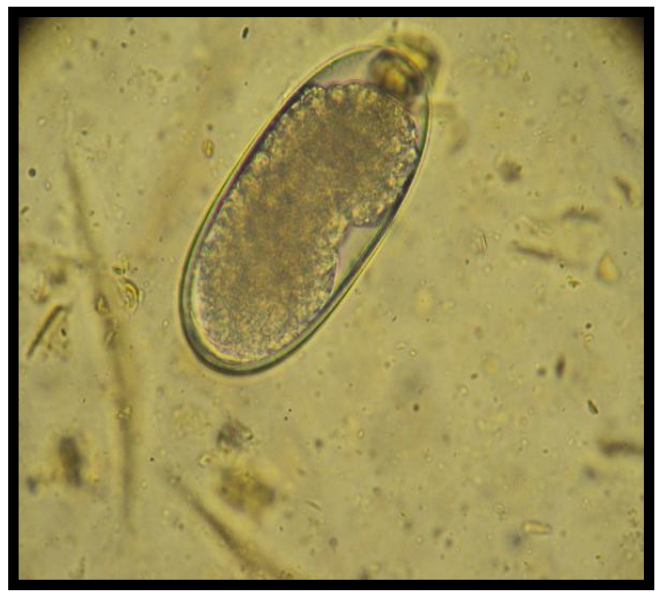

Fig. (6)Egg of Tricostrongylus axei. in direct smear method $40 \mathrm{X}$

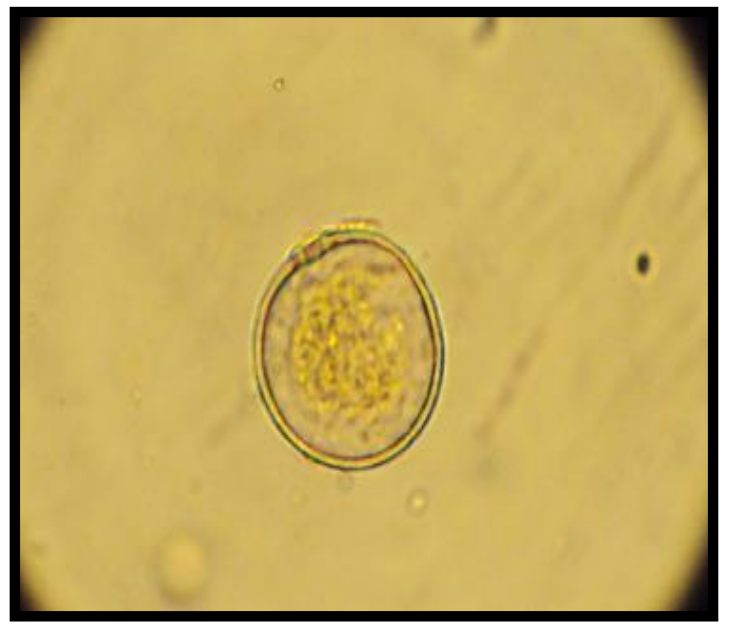

fig.(8) oocyst of Eimeria spp. in flotation method $40 \mathrm{X}$

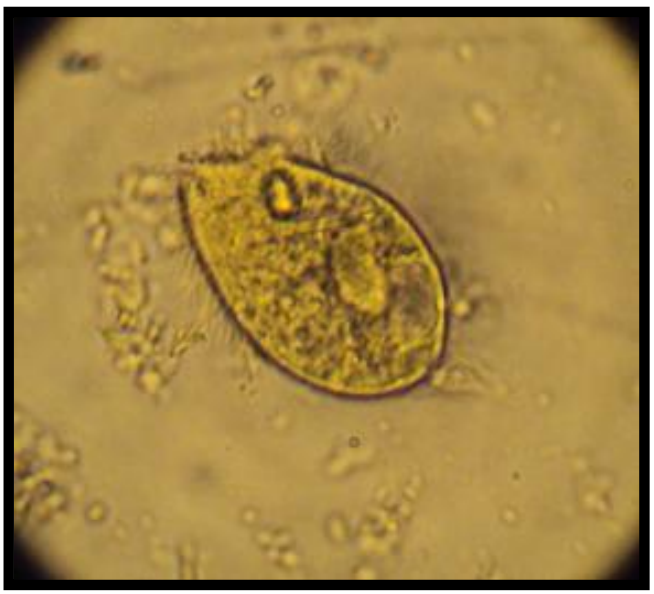

Fig.(7) Trophozoit of B.coli . in direct smear method $40 \mathrm{X}$

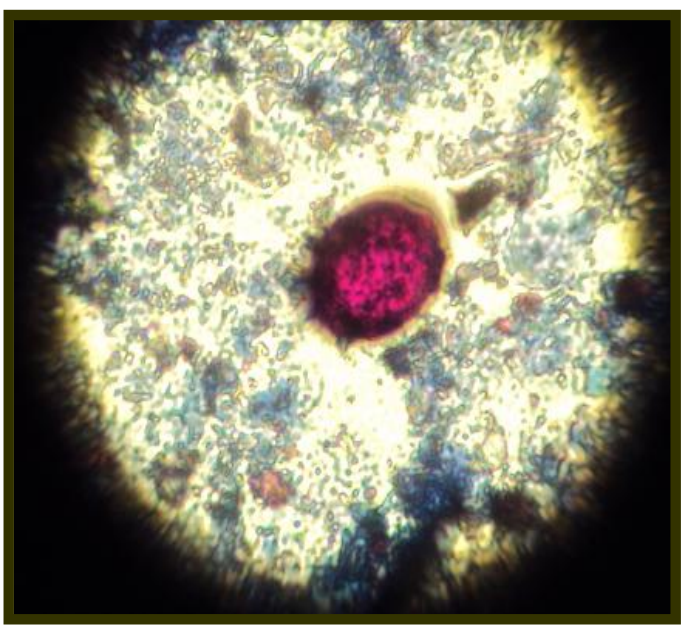

Fig .(9) Oocyst of Cryptosporidium spp. in acid fast stain method $100 \mathrm{X}$. 


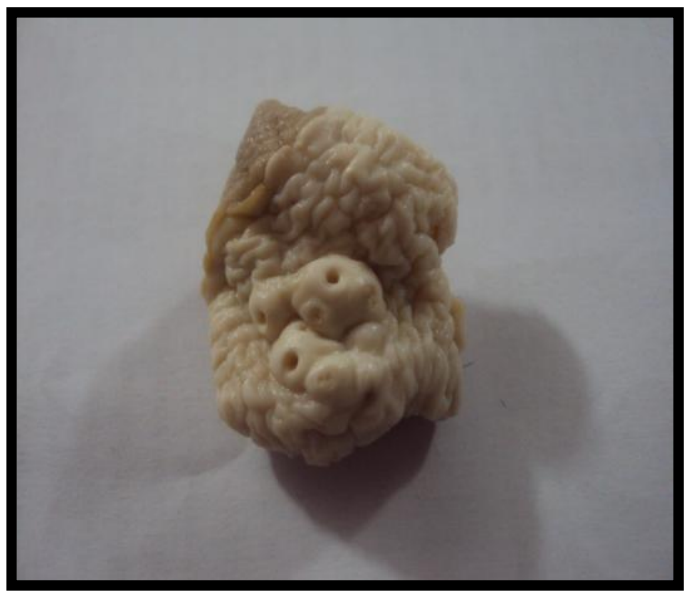

Fig. (10)Deep pits in gastric wall of donkeys

The parasitic infection was divided into single parasitic infection, it was $50 \%$, $28.57 \%$ and mixed infection, it was $50 \%$,

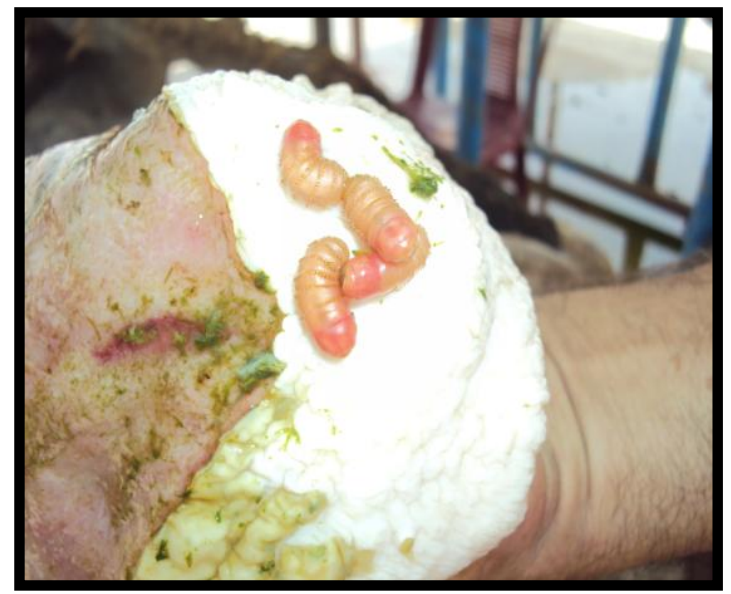

Fig. (11) Four larvae on the internal wall of donkey's stomach

$71.42 \%$ in horses and donkeys respectively, table 4 .

Table (4) reveals the number and percentage of single and mixed infection in horses and donkeys:

\begin{tabular}{|c|c|c|c|c|c|c|c|c|c|c|c|c|}
\hline \multirow{3}{*}{ Animal } & \multicolumn{4}{|c|}{ Single infection } & \multirow{2}{*}{\multicolumn{2}{|c|}{ Total }} & \multicolumn{4}{|c|}{ Mixed infection } & \multirow{2}{*}{\multicolumn{2}{|c|}{ Total }} \\
\hline & \multicolumn{2}{|c|}{ Nematodes } & \multicolumn{2}{|c|}{ Protozoa } & & & \multicolumn{2}{|c|}{$\begin{array}{c}\text { Nematodes } \\
\& \\
\text { Protozoa }\end{array}$} & \multicolumn{2}{|c|}{$\begin{array}{l}2 \text { species of } \\
\text { Nematodes }\end{array}$} & & \\
\hline & No & $\%$ & No & $\%$ & No. & $\%$ & No & $\%$ & No & $\%$ & No. & $\%$ \\
\hline Horse & 18 & 40.91 & 4 & 9.09 & 22 & 50 & 15 & 34.09 & 7 & 15.90 & 22 & 50 \\
\hline Donkey & 15 & 26.78 & 1 & 1.78 & 16 & 28.57 & 28 & 50 & 12 & 21.42 & 40 & 71.42 \\
\hline Total & 33 & 33 & 5 & 5 & 38 & 38 & 43 & 43 & 19 & 19 & 62 & 62 \\
\hline
\end{tabular}

\section{Discussion}

According to faecal examinations, the prevalence of Strongylidae was 50\% in horses that accordance with (11) recorded $55.5 \%$ and disagreement with the results of $(5,12,13)$ who recorded $72.9 \%, 86.4 \%$ and $68 \%$ respectively. Strongyles have large numbers of genera and species so their percents usually represented (75-100) percent of whole nematodes infections (14). On other hand among 56 donkeys there were $22(57.14 \%)$ donkeys given positive result to Strongylus spp. infection that was lower than the result of $(15,7)$ who recorded $100 \%, 70 \%$ respectively. Regarding to the percent of Parascaris equorum in horses was $40.90 \%$ which was similar to the results were recorded by (11, 5) $45 \%$ and $38.4 \%$ respectively, while it was differed with (3) who found few numbers of worms especially in young horses in Baghdad, and (6) 64\% in Basrah. In donkeys, the rate of infection was $32.14 \%$ that similar with the result of (6) $40 \%$ and corresponding with the finding of 
(13 and 7) who recorded the same rate (20\%). Trichostrongylus axei was confirmed in $25 \%$ of examined horses, this result higher than the results of (3) of horserace in Baghdad and (5) who recorded $10 \%$ and $8 \%$ respectively. While it was not recorded by $(9,4,15)$. In donkeys, it was $32.14 \%$ that similar to (17, 7) was $40 \%$ and $33.35 \%$ but differed with (16) $6.6 \%$ and it was not be evidence for $(15,18)$. In mules $P$. equorum recorded by (19) $63.33 \%$. The clinical disease of P.equorum related with the conditions that allow the accumulation of infective eggs because it doesn't has free living larvae, and larvae two inside egg is infective stage and this mostly occur indoor pens (20). Trichostrongylus axei was confirmed $25 \%$ of examined horses, this result higher than the results of (3) of horserace in Baghdad and (5) who recorded $10 \%$ and $8 \%$ respectively, while it was not recorded by $(9,4,15,13)$. In donkeys, it was $32.14 \%$ that similar to $(17,7)$ which was $40 \%$ and $33.35 \%$ but differed with (16) $6.6 \%$ and it was not be evidence for $(17,18)$. In mules, it was $8.66 \%$ (19). The prevalence of Strongyloides westri in horses was $22.72 \%$ more than the results of $(11,5)$ which was $1.6 \%$ and $11.2 \%$. In donkeys the percentage of $S$. westri was $28.57 \%$ that elevated than the resultes of $(15,7)$ $12.34 \%$ and $10 \%$. Oxyuris equi was verified $11.36 \%$ in horses, it was higher than the results of (5) $4.8 \%$ and (21) $7 \%$ who defined in the post mortum examination. while $O$. equi not recorded by $(3,9,4)$. In donkey $O$. equi was $17.85 \%$ this differs with the results (6) $6.6 \%$, and (16) $6.6 \%$. The differences in the percentages of infection with $S$. westri and $O$. equi may due to lack of treatment of horses and poor hygiene measures in stables. Related to Dictyocalus arnfieldi was not confirm in horses in this study, and the studies $(4,15,13)$ in addition to $D$. arnfieldi not recorded in the mules by (19). While it recorded by $(11,9,5)$ who verified $0.04 \%, 2 \%$, and $24 \%$ respectively. In donkeys, it was $17.85 \%$ in agreement with (6) $13.3 \%$, but disagreement with (17) was recovered $32 \%$. The variation among species of equines that were examine in the different above studies play a role in difference of infection with $D$. arnfieldi. The gastrointestinal parasites were more prevalent in cold season than hot and rainy season. The infection with helminthes parasites was notice to be higher at the beginning of the rainy season (22). The trematodes were recorded neither horses nor donkeys in this study although the sedimentation technique was use for several times and these results were comparable to the finding of (3-5). (20) indicated that the horses resistant to trematodes infection. It overcomes on the migration of this worm inside their bodies in early stages, so a few numbers are reaching to liver. The recent research was recorded the infection with four genera of intestinal protozoa. Eimeria Spp., was $6.81 \%$ in horses as mixed infections, like the result of $(9,8)$ they recorded $4 \%$ and $10.96 \%$ and unlike the findings of $(11,13)$ who recorded $0.6 \%$ and $0.5 \%$ respectively. In donkeys was $10.71 \%$ differ with (15) who recorded $3.7 \%$. Cryptosporidium spp. was verify $20.45 \%$ in horses similar to the results of $(23,13)$ were recorded $17 \%$ and $15 \%$ respectively and differed with the results of (8) $8.14 \%$. In donkeys was $19.64 \%$ differed than the result of (24) who recorded $9.4 \%$ in foals and mature horses in western Poland as the overall infection. Balantidium coli prove $15.9 \%$ in horses and $17.85 \%$ in donkeys, our finding nearly similar to the results of (25) in human $12 \%$ and in pigs $33 \%$ and disagree with (8) who recorded $85.71 \%$ in horses. In the last, only two donkeys (3.57\%) affected with Entameoba coli as mixed infections. When the post morteum examination was done to the infected donkey, Gastrophilus intestinalis larvae of botfly were found attached in the wall of the stomach in pyloric region. It cause a pit at the site of attachment this similar with the result of $(5,18)$. 


\section{References}

1. Konteno, G. (1979). Daily life in Babylon and Ashore. Translation of Saleem Taha Al-Tekriti. Dar Al-Huria. P:103.

2. Donald H. and Bliss, Ph.D. (2000). The Control of Gastro-Intestinal Nematode Parasites in Horses with Emphasis on Reducing Environmental Contamination."A New Control Strategy for an Old Problem." Mid America Ag. Res., Verona, WI.

3. Yaecob A.Y., Wafaa H., Altaif K.I. (1988). Survey of gastrointestinal helminthes of horses in Baghdad city. Vet. Med. J. 12: 221-230

4. Alkhafaji N.G., Alsaad K.M. (1996). Common gastrointestinal parasites in drought horses in Mosul city. Mosul. Iraq. Vet. Med. J. 9: 51-60.

5. Abdul-Majeed, M. O.(2004). Clinical, Pathological and treatment study in horses infected with gastrointestinal worms in Mosul. Thesis Ms.C., vet. Med. Mosul.

6. Alammara G.J., Alali S.J., Abdul Aziz S.A. (2008).Prevalence of Parascaris equorum infections in Karmat Ali in Basrah. Basrah J. for Vet. Res. 7: 34- 48.

7. Esmaeel, S.A. (2009). Clinical and hematological study of the internal parasite in native donkeys in Mosul city. Iraq J. for Vet. Res. Vol. 24 (2): 129-130.

8. Alharis, K. M. (2001). Survey of the intestinal protozoa in the horses in Baghdad city, thesis M.S.C. Vet. Med. Baghdad.

9. Alalousi, T. I., Arselan, S. H., Zangana, I. Q.(1994). Study of some intestinal infections of horses in Mosul, Iraq. Vet. Med. J. 2: 85-91.

10. Charles M. Hendrix, Ed. Robinson (2006). Diagnostic Parasitology for veterinary technique. Mosby Elsevier, $3^{\text {rd }}$ ed.

11. Epe, C., Ising - Volmer, S. and Stoye, M. (1993). Parasitological fecal studies of equides, dogs, cats \& hedgehogs during the years 19841991. Dtsch Tierazll Wochenschr, 100(11): 426-428.

12. Veli YÝlg.r .IRAK, Ender G.LEÚEN (2005). The Prevalence of Strongyle Infections and Persistent Efficacy of Pyrantel Embonate, Ivermectin and Moxidectin in Turkish Horses. Turk. J. Vet. Anim. Sci. (29): 175-181. (C) T.BÜTAK

13. Tavassoli, M., Dalir-Naghaden, B., Esmaeili-Sanis, S. (2010). prevalence of gastrointestinal parasites in working horses.(Abstract) Pol. J. Sci. 13(2): 318-324.

14. Bowmen, D. D., Lynn, R. C. and Eberhard, M. L. (2003). Georgis Parasitology for veterinarians. $8^{\text {th }}$ ed., Saunders, Elsevier Science, USA.

15. Uslu U, Guclu F(2007). Prevalence of endoparasite in horses \& donkeys in turkey. Bull Vet Inst. Pulawy. 2007. 51:237-240

16. Hosseini, S. H., Meshgi, B., Eslami, A., Bokai, S., Sobhani, M., Ebrahimi Samani, R. (2009). Prevalence and biodiversity of helminth parasites in donkeys (Equus asinus) in Iran. Int. J. Vet. Res. 3, 2: 95-99.

17. Ayele G, Feseha. G., Bojia E., Joe A. (2006). Prevalence of gastrointestinal parasite of donkeys in Dugda Bora District, Ethiopia. Livestock Res. For Rural development . 18 (10).

18. Getachew M., Trawford A., Feseha G., Reid S.W. gastrointestinal parasites of working donkeys of Ethiopia. (2009) Trop Anim. Health Prod. 42(1): 27-33. pubmed (abstract)

19. Alani, A.J., Fatoohy, F.A.M. \& Saleem, A.N. (1992). Gastrointestinal parasites and their clinical effects on mules in 
Mosul (Iraq). Iraq J. vet. Med.5 (1): 19-30.

20. Radostits, O.M., Gay, C.C., Blood, D.C. \& Hinchcliff, K.W. (2000). Veterinary medicine: A text book of the diseases of cattle.

21. Boxell, A.C., Gibson, K.T., Hobbs, R.P. \& Thompson, R.C.A. (2004). Occurrence of gastrointestinal parasites in horses in metropolitan Perth, Western Australia. Aust. Vet. J. 82(1-2): 91-95.

22. Seri, H. I., Hassan, T., Salih, M. M. and Abakar, A. D. (2004). A Survey of Gastrointestinal Nematodes of Donkeys. (Equus Bsinus) in Khartoum State, Sudan. Journal of Animal and Veterinary Advances 3 (11): 736-
739, 2004. Grace Publications Network.

23. Olson, M. E., Thoralkson, C. L. \& McAllister, T. A. (1997). Giardia and Cryptospordium in Canadian farm animals. Vet. Parasitol. 68: 375-381

24. Majewska A.C., Werner A., Sulima P., Luty, T. (1999). Survey on equine cryptosporidiosis in Poland \& the possibility of zoonatic transmission. Ann Agric Environ Med. 6: 161-165

25. Devera R., Requena I, Velasques V., Castillo H., Guevara R., Desousa M., Marin C. \& Sitva M. (1999). Balantidiasis in a rural community from Bolivar states, Venezuela Bol. Chil. Parasito. 54(1): 7-12, Med. Line. Abst.

\section{انتشار الطفيليات الداخلية في الخيول والحمير في محافظة الديوانية$$
\text { هبة يحيى وناس كلية الطب البيطري عبد الله داود جامعة القادية غيداء عباس جاسم }
$$

شملت الدراسة جمع 100 عينة براز من الخيول و الحمير (44 من الخيول و 56 من الحمير) ومن كلا الجنسين

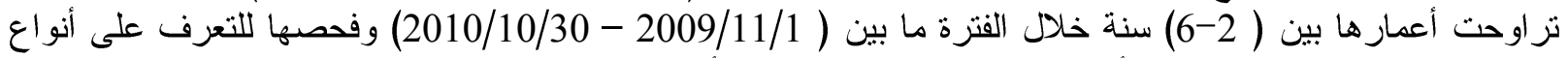

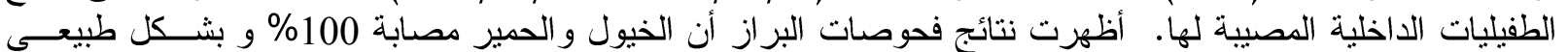

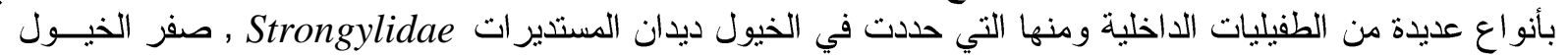
Tricostrongylus axei الديدان الخيطية equorum Parascaris

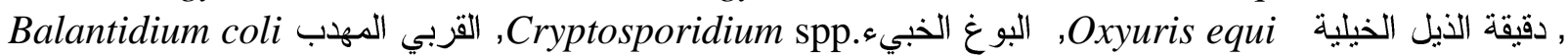

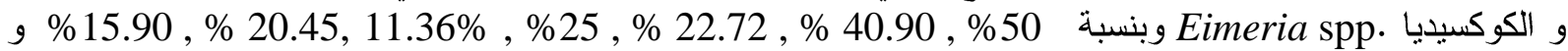
6.81 \% على التو الي. آما الحمير فكانت مصابة بالمستديرات

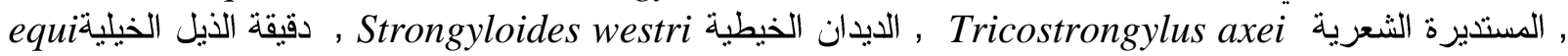
, Oxyuris

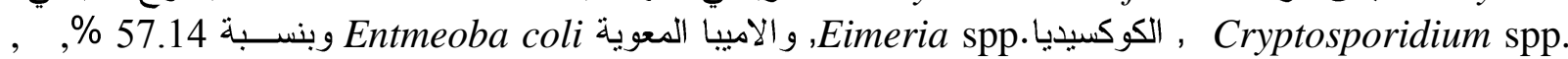
\% 32.14

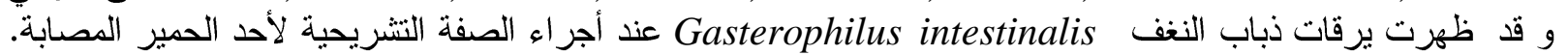

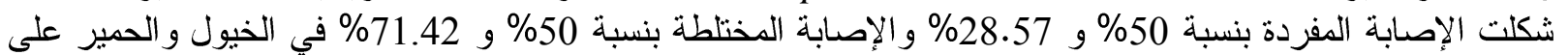

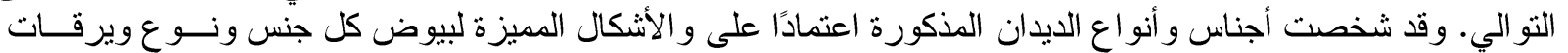

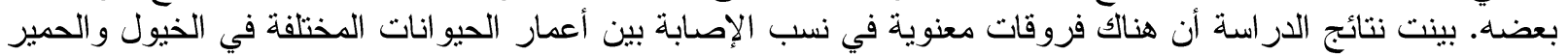
( تحت مستوى احتمال 0.01 ) بينما لا توجد فروقا معنوية في نسب الإصابة بين الذكور و الإناث تحت مستوى احتمـال 